\title{
Modulators of hypothalamic-pituitary-gonadal axis for the control of spermatogenesis and sperm quality in vertebrates
}

\author{
Rosaria Meccariello ${ }^{1}$, Silvia Fasano ${ }^{2}$, Riccardo Pierantoni ${ }^{2 *}$ and Gilda Cobellis ${ }^{2}$ \\ 1 Dipartimento di Scienze Motorie e del Benessere (DiSMEB), Parthenope University of Naples, Naples, Italy \\ ${ }^{2}$ Department of Experimental Medicine, Second University of Naples, Naples, Italy \\ ${ }^{*}$ Correspondence: riccardo.pierantoni@unina2.it \\ Edited by: \\ Cunming Duan, University of Michigan, USA \\ Reviewed by: \\ Takayoshi Ubuka, Waseda University, Japan
}

Keywords: spermatogenesis, sperm quality, vertebrates, hypothalamic-pituitary-gonadal, HPG-axis

In both male and female, gametogenesis is regulated by hypothalamus-pituitary-gonadal axis (HPG) that corresponds to the hormonal axis, gonadotropin-releasing hormone (GnRH)gonadotropins-steroids. Indeed, the main target of $\mathrm{GnRH}$ is the gonadotrope cells, located in the adenohypophysis. These, in turn, release two gonadotropin hormones, the follicle stimulating hormone (FSH) and the luteinizing hormone ( $\mathrm{LH})$, that through the main circulation reach gonads to regulate gametogenesis via the synthesis of steroid hormones. It is now accepted that further non-steroid factors support germ cell progression via intragonadal action (1).

The first evidence of relationships between pituitary and gonad came out in 1905 from a study on castrated animals, which showed hypertrophy of the pituitary gland (2). Later in 1910, Homans and co-workers (3) showed that the "experimental hypophysectomy" in prepubertal animals induced persistence of gonadal infantilism. Surprisingly, only in 1930 the reciprocal relationship between gonads and pituitary via feedbacks was elucidated (4). Later in 1954, the long feedback connecting the hypothalamus and the gonad was described (5), but only in the 1970s did the picture become complete through the description of the short- and ultrashort-feedback mechanisms. It was at the end of the 1970s that paracrine and autocrine communications were described as being carried out also by "classic" hormones (6). In particular, it was observed that chemical messengers acting through the bloodstream could be produced in multiple tissues, not necessarily including any of the traditional ductless glands. This observation led to the new definition of what constitutes a hormone by considering its function (ó $\rho \mu$ á $\omega$, to excite) rather than its source (ductless glands). A hormone may now be considered as a chemical messenger acting through endocrine (bloodstream), paracrine, and/or autocrine (local) routes. Furthermore, any chemical mediators, not only hormones, besides the endocrine route may also act locally in the gonad $(7,8)$.

In the testis, it has been demonstrated that a network of intragonadal endocrine, paracrine, and autocrine factors converge in a complex stage-specific multi-factorial control of spermatogenesis (6). Indeed, it has been documented that traditional endocrine control does not fully account for testis physiology, including steroidogenesis and spermatogenesis, and an intragonadal network of autocrine and/or paracrine regulators also exist, which regulates germ cell progression and development of qualitatively mature spermatozoa via cell-to-cell communication $(9,10)$.

The aim of this Research Topic is to give a comparative track on HPG axis activity for the control of spermatogenesis and quality sperm production. Through synergy between the respective specializations of all the authors, this Research Topic reviews the emerging knowledge about neuroendocrine and local mediators controlling progression and maturation of germ cells in male vertebrates.

The Research Topic firstly reports the description of a primitive HPG in hagfish, one of the only two extant members of the class of agnathans - the most primitive vertebrates known, living or extinct - providing evidence that there are neuroendocrinepituitary hormones that share common structure and functional features compared to later evolved vertebrates (11). A complex set of neuronal network converges information concerning environmental, stressors, and metabolic cues onto the centers governing the reproductive axis. In this respect, the most recent discoveries in the central pathways integrating metabolism and reproduction in teleost fish have been reviewed here (12). However, the list of central and local modulators of HPG is growing up and currently comprises gonadotropin-inhibiting hormone, firstly identified in Japanese quail in 2000 (13) as an inhibitor of gonadotropin synthesis and release but subsequently identified in all vertebrates (14); classical female hormone such as estrogens that elicit their activity through genomic and non-genomic mechanisms (15); lastly endocannabinoids (16), a set of lipid mediators that share some of the effects with delta-9-tetrahydrocannabinol ( $\Delta^{9}$-THC), the active principle of marijuana plant, Cannabis sativa. The middle part of this Research Topic comprises a set of four review articles dedicated to the control of fetal and postnatal development of both Leydig and germ cells and to the intragonadal networks controlling the progression of the spermatogenesis (17-20); two original research articles point out the discussed involvement of new players such as kisspeptins in the local control of testis physiology (21) and the difficulties to reproduce the testicular environment in vitro to get a successful spermatogenesis (22). Lastly, in order 
to gain the production of high quality sperm, the importance of antioxidant defenses (23), GnRH, kisspeptins, estradiol (24), and endocannabinoids (25) has been reported.

The last part of this Research Topic is focused on disease models such as Kallmann Syndrome (26), blindness (27), lysosomal storage disease (28), and cryptorchidism (29).

We hope that this contribution published in Frontiers in Endocrinology may represent a comprehensive guide in the plethora of data concerning the control of male reproductive activity and that readers might find new insights for the building of general models.

\section{REFERENCES}

1. Cobellis G, Meccariello R, Pierantoni R, Fasano S. Intratesticular signals for progression of germ cell stages in vertebrates. Gen Comp Endocrinol (2003) 134:220-8. doi:10.1016/S0016-6480(03)00281-8

2. Fichera G. Sur hypertrophie de la gland pituitarie consécutive à la castration. Arch Ital Physiol (1905) 43:26.

3. Crowe SJ, Cushing H, Homans J. Experimental hypophysectomy. Bull Johns Hopkins Hosp (1910) 21:127-70.

4. Moore CR, Price D. The question of sex hormone antagonism. Proc Soc Exp Biol Med (1930) 28:38-40. doi:10.3181/00379727-28-5145

5. Flerkó B. Zur hypothalamischen steuerung der gonadotropen function der hypophise. Acta Morph Acad Sci Hung (1954) 4:475-92.

6. Pierantoni R, Cobellis G, Meccariello R, Fasano S. Evolutionary aspects of cellular communication in the vertebrate hypothalamo-hypophysio-gonadal axis. Int Rev Cytol (2002) 218:69-141. doi:10.1016/S0074-7696(02)18012-0

7. Pierantoni R, Cobellis G, Meccariello R, Cacciola G, Chianese R, Chioccareli T, et al. Testicular gonadotropin-releasing hormone activity, progression of spermatogenesis and sperm transport in vertebrates. Ann N Y Acad Sci (2009) 1163:279-91. doi:10.1111/j.1749-6632.2008.03617.x

8. Cacciola G, Chioccarelli T, Fasano S, Pierantoni R, Cobellis G. Estrogens and spermiogenesis: new insights from type 1 cannabinoid receptor knockout mice. Int J Endocrinol (2013) 2013:501350. doi:10.1155/2013/501350

9. Cacciola G, Chioccarelli T, Altucci L, Ledent C, Mason JI, Fasano S, et al. Low 17beta-estradiol levels in CNR1 knock-out mice affect spermatid chromatin remodeling by interfering with chromatin reorganization. Biol Reprod (2013) 88:1-12. doi:10.1095/biolreprod.112.105726

10. Cacciola G, Chioccarelli T, Altucci L, Viggiano A, Fasano S, Pierantoni R, et al. Nuclear size as estrogen-responsive chromatin quality parameter of mouse spermatozoa. Gen Comp Endocrinol (2013) 193:201-9. doi:10.1016/j.ygcen.2013.07. 018

11. Nozaki M. Hypothalamic-pituitary-gonadal endocrine system in the hagfish. Front Endocrinol (2013) 4:200. doi:10.3389/fendo.2013.00200

12. Shahjahan M, Kitahashi T, Parhar IS. Central pathways integrating metabolism and reproduction in teleosts. Front Endocrinol (2014) 5:36. doi:10.3389/fendo. 2014.00036

13. Tsutsui K, Saigoh E, Ukena K, Teranishi H, Fujisawa Y, Kikuchi M, et al. A novel avian hypothalamic peptide inhibiting gonadotropin release. Biochem Biophys Res Commun (2000) 275:661-7. doi:10.1006/bbrc.2000.3350

14. Ubuka T, Son YL, Tobari Y, Narihiro M, Bentley GE, Kriegsfeld LJ, et al. Central and direct regulation of testicular activity by gonadotropin-inhibitory hormone and its receptor. Front Endocrinol (2014) 5:8. doi:10.3389/fendo.2014. 00008

15. Chimento A, Sirianni R, Casaburi I, Pezzi V. Role of estrogen receptors and $G$ protein-coupled estrogen receptor in regulation of hypothalamus-pituitarytestis axis and spermatogenesis. Front Endocrinol (2014) 5:1. doi:10.3389/fendo. 2014.00001
16. Bovolin P, Cottone E, Pomatto V, Fasano S, Pierantoni R, Cobellis G, et al. Endocannabinoids are involved in male vertebrate reproduction: regulatory mechanisms at central and gonadal level. Front Endocrinol (2014) 5:54. doi: 10.3389/fendo.2014.00054

17. Ivell R, Heng K, Anand-Ivell R. Insulin-like factor 3 and the HPG axis in the male. Front Endocrinol (2014) 5:6. doi:10.3389/fendo.2014.00006

18. Rossi P, Dolci S. Paracrine mechanisms involved in the control of early stages of mammalian spermatogenesis. Front Endocrinol (2013) 4:181. doi:10.3389/ fendo.2013.00181

19. Ricci G, Catizone A. Pleiotropic activities of HGF/c-Met System in testicular physiology: paracrine and endocrine implications. Front Endocrinol (2014) 5:38. doi:10.3389/fendo.2014.00038

20. Grimaldi P, Di Giacomo D, Geremia R. The endocannabinoid system and spermatogenesis. Front Endocrinol (2013) 4:192. doi:10.3389/fendo.2013.00192

21. Mei H, Doran J, Kyle V, Yeo SH, Colledge WH. Does kisspeptin signaling have a role in the testes? Front Endocrinol (2013) 4:198. doi:10.3389/fendo.2013.00198

22. Reda A, Hou M, Landreh L, Kjartansdóttir KR, Svechnikov K, Söder O, et al. In vitro spermatogenesis - optimal culture conditions for testicular cell survival, germ cell differentiation, and steroidogenesis in rats. Front Endocrinol (2014) 5:21. doi:10.3389/fendo.2014.00021

23. Guerriero G, Trocchia S, Abdel-Gawad FK, Ciarcia G. Roles of reactive oxygen species in the spermatogenesis regulation. Front Endocrinol (2014) 5:56. doi:10.3389/fendo.2014.00056

24. Meccariello R, Chianese R, Chioccarelli T, Ciaramella V, Fasano S, Pierantoni $\mathrm{R}$, et al. Intratesticular signals regulate germ cell progression and production of qualitatively mature spermatozoa in vertebrates. Front Endocrinol (2014) 5:69. doi:10.3389/fendo.2014.00069

25. Maccarrone M. Endocannabinoids as markers of sperm quality: hot spots. Front Endocrinol (2013) 4:169. doi:10.3389/fendo.2013.00169

26. Garaffo G, Provero P, Molineris I, Pinciroli P, Peano C, Battaglia C, et al. Profiling, bioinformatic, and functional data on the developing olfactory/GnRH system reveal cellular and molecular pathways essential for this process and potentially relevant for the Kallmann syndrome. Front Endocrinol (2013) 4:203. doi:10.3389/fendo.2013.00203

27. Bellastella A, De Bellis A, Bellastella G, Esposito K. Opposite influence of light and blindness on pituitary-gonadal function. Front Endocrinol (2014) 4:205. doi:10.3389/fendo.2013.00205

28. Piomboni P, Governini L, Gori M, Puggioni E, Costantino-Ceccarini E, Luddi A. New players in the infertility of a mouse model of lysosomal storage disease: the hypothalamus-pituitary-gonadal axis. Front Endocrinol (2014) 4:204. doi:10.3389/fendo.2013.00204

29. Cobellis G, Noviello C, Nino F, Romano M, Mariscoli F, Martino A, et al. Spermatogenesis and cryptorchidism. Front Endocrinol (2014) 5:63. doi:10.3389/ fendo.2014.00063

Conflict of Interest Statement: The authors declare that the research was conducted in the absence of any commercial or financial relationships that could be construed as a potential conflict of interest.

Received: 21 July 2014; accepted: 02 August 2014; published online: 18 August 2014. Citation: Meccariello R, Fasano S, Pierantoni R and Cobellis G (2014) Modulators of hypothalamic-pituitary-gonadal axis for the control of spermatogenesis and sperm quality in vertebrates. Front. Endocrinol. 5:135. doi: 10.3389/fendo.2014.00135

This article was submitted to Experimental Endocrinology, a section of the journal Frontiers in Endocrinology.

Copyright (C) 2014 Meccariello, Fasano, Pierantoni and Cobellis. This is an open-access article distributed under the terms of the Creative Commons Attribution License (CC $B Y)$. The use, distribution or reproduction in other forums is permitted, provided the original author(s) or licensor are credited and that the original publication in this journal is cited, in accordance with accepted academic practice. No use, distribution or reproduction is permitted which does not comply with these terms. 